\title{
EDUKASI DENGAN MEDIA PERMAINAN ULAR TANGGA TERHADAP PENGETAHUAN KEBERSIHAN GIGI DAN MULUT PADA SISWA SEKOLAH DASAR
}

\section{EDUCATION ABOUT KNOWLEDGE OF DENTAL AND MOUTH CLEANING USING SNAKE LADDER GAME MEDIA FOR ELEMENTARY SCHOOL STUDENTS}

\author{
Pinky Nova Ghea ${ }^{1)}$, Abduh Ridha'), Selviana ${ }^{3 *}$, \\ 1,2,3 Program Studi Kesehatan Masyarakat: Universitas Muhammadiyah Pontianak, \\ Jl. Jenderal Ahmad Yani No.111, Pontianak \\ *email: pnovagheaa@gmail.com
}

\begin{abstract}
The use of attractive media is needed to increase the knowledge of elementary school children regarding dental and oral hygiene. The selection of media needs to be tested to increase knowledge. The purpose of this study was to determine the effectiveness of education about dental and mouth cleaning using Snake Ladder Game media at 'SD Muhammadiyah 2 Pontianak'. The present research was Quasi Experiment with Pre and Posttest Group. The number of samples was 40 students from Learning Group IV A. This study was conducted for 5 consecutive days in Agustus. The results showed that the education using game media, The Snake and Ladders, at SD Muhammadiyah 2 Pontianak' increased the knowledge of the experimental group more significantly than that of the control group, who were not given intervention. It is proven by the knowledge score of the experimental group, from 52.25 before having intervention to 89.25 with $P$-value $=0,000$, while the control group increased from 52.25 to 55.25 with $P$-value $=0.137$. Based on the results of the study, it was suggested to the relevant agencies to adopt dental and oral hygiene intervention models by giving the Snakes Ladder Game media to students to improve students' knowledge about dental and oral hygiene in elementary school students.
\end{abstract}

Keywords: Maintaining Dental, Oral Hygiene, Snake Ladder Game Media, Student Knowledge.

\begin{abstract}
ABSTRAK
Penggunaan media yang menarik diperlukan guna meningkatkan pengetahuan anak sekolah dasar mengenai kebersihan gigi dan mulut. Pemilihan media perlu diuji untuk meningkatkan pengetahuan. Tujuan penelitian ini untuk mengetahui efektifitas edukasi dengan media Permainan Ular Tangga terhadap pengetahuan kebersihan gigi dan mulut pada siswa Sekolah Dasar di SD Muhammadiyah 2 Pontianak. Penelitian ini adalah Quasi Eksperiment dengan Pre and Posttest Group. Jumlah sampel sebanyak 40 siswa dari kelas IV A. Penelitian ini dilakukan selama 5 hari berturut-turut pada bulan Agustus. Hasil penelitian menunjukkan bahwa pemberian edukasi dengan media Permainan Ular Tangga di SD Muhammadiyah 2 Pontianak pada siswa kelompok eksperimen adalah signifikan. Ini dibuktikan dengan skor pengetahuan siswa kelompok eksperimen sebelum intervensi 52,25 meningkat menjadi 89,25 dengan $P$ value $=0,000$ sedangkan kelompok kontrol pretest 52,25 meningkat menjadi 55,25 dengan $P$ value $=0,137$. Merujuk kepada hasil penelitian ini, disarankan kepada instansi terkait agar mengadopsi model intervensi kebersihan gigi dan mulut dengan pemberian media Permainan Ular Tangga kepada siswa. Tujuannya adalah untuk meningkatkan pengetahuan siswa tentang kebersihan gigi dan mulut pada siswa sekolah dasar.
\end{abstract}

Kata kunci: Menjaga Kebersihan Gigi, Mulut, Media Permianan Ular Tangga, Pengetahuan Siswa. 


\section{PENDAHULUAN}

Perilaku hidup sehat turut menjadi faktor penting penentu Indeks Pembangunan Manusia (IPM). Untuk mendukung peningkatan IPM ini, maka perlu didukung melalui pendidikan kesehatan. Pendidikan kesehatan adalah upaya untuk mempengaruhi atau mengajak orang lain agar melaksanakan perilaku hidup sehat. Pendidikan kesehatan khususnya kesehatan gigi mengkaji tentang kebersihan mulut, diet, konsumsi gula, dan kunjungan berkala ke dokter gigi. Ini lebih ditekankan kepada anak yang berisiko tinggi terhadap penyakit gigi seperti karies dan penyakit periodontal. Penyampaian informasi tentang pendidikan kesehatan ini sebaiknya bersifat individual dan dilakukan secara terus menerus serta harus menimbulkan motivasi dan tanggung jawab anak untuk memelihara kesehatan mulutnya (Pitauli, 2010).

Gigi merupakan organ vital dalam tubuh kita. Salah satu fungsi gigi adalah sebagai alat pengunyah makanan dan membantu melumatkan makanan dalam mulut untuk membantu kerja organ pencernaan. Dengan demikian, makanan dapat diserap tubuh dengan baik (Balqis, 2014). Anak usia sekolah yaitu, anak dengan rentang usia 6-12 tahun merupakan kategori usia yang beresiko mengalami masalah pada gigi dan mulut. Usia 6-8 tahun merupakan usia dimana gigi susu mulai berganti menjadi gigi permanen yang disebut masa gigi campuran. Pada usia tersebut, anak-anak perlu mendapatkan pendidikan atau edukasi tentang kesehatan gigi dan mulut dalam upaya meningkatkan pengetahuan mereka dalam menjaga kesehatan gigi dan mulut untuk mencegah terjadinya kerusakan gigi (Sara, 2016).
Menurut WHO (2016), Early Childhood Caries (ECC) adalah penyakit tertinggi di seluruh dunia. Prevalensi antara anak usia 3-5 tahun bervariasi di beberapa negara. Data dari Amerika Serikat menunjukkan prevalensi yang lebih tinggi daripada daripada negara-negara Eropa dengan 40\% anak-anak menderita karies pada usia taman kanak-kanak. Di Inggris $12 \%$ anak-anak berusia 3 tahun menderita karies. Di Jepang, Survei Kesehatan Oral Nasional 2011 menunjukkan bahwa 25\% anak usia 3 tahun mengalami karies dengan tingkat gigi utama yang rusak. Hasil studi menunjukkan prevalensi yang lebih tinggi $36-85 \%$ di Asia, 38-45\% di Afrika dan 22-61\% di Timur Tengah. Kamboja dan Indonesia telah melaporkan bahwa prevalensi dan tingkat keparahan ECC yang tinggi sejak 90\% dari 3-5 tahun memiliki karies dengan tingkat gigi yang rusak, hilang dan penuh (dmft) lebih tinggi. Prevalensi ECC kelompok usia 3-5 tahun berada di kisaran $50-60 \%$ di Iran, Senegal dan Thailand. Namun, tingkat keparahannya menurun di beberapa negara, seperti Thailand. Data menunjukkan bahwa prevalensi ECC meningkat seiring bertambahnya usia dan dapat dimulai sejak awal 12 bulan (Nigeria). Laporan dari kota Bangalore, India, kelompok usia lebih muda pada usia 8-48 bulan telah menunjukkan prevalensi karies $27,5 \%$ dan def rata-rata 0,85.

RISKESDAS Provinsi Kalimantan Barat tahun 2013 melalui risetnya memperjelas melalui poin-poin yang lebih terperinci bahwa penduduk dengan rentang usia 5-9 tahun menerima perawatan gigi berupa penumpatan (penambalan) sebesar $5,1 \%$, menjalani pengobatan gigi sebesar 93,5\%, melakukan pencabutan gigi sebesar $1,5 \%$, dan melakukan perawatan gusi sebesar $0,2 \%$. Anak-anak dalam rentang usia 
10-14 tahun melakukan penumpatan (penambalan) gigi sebesar 3,5\%, pengobatan gigi sebesar $88,8 \%$, pencabutan gigi sebesar $24,8 \%$, dan melakukan perawatan gusi sebesar $0,5 \%$. Analisis data tentang anak yang mengalami karies gigi yang diperoleh dari rentang usia 12-14 tahun menunjukkan bahwa sebesar 60,1\% anak di Provinsi Kalimantan Barat mengalami karies aktif, jumlah anak yg bebas dari karies sebesar 31,2\%, dan yang pernah memiliki pengalaman pada karies gigi sebesar 68,8\%. Rekapitulasi pada 14 Kabupaten/ Kota di provinsi Kalimantan Barat didapatkan hasil bahwa penduduk yang bermasalah pada gigi dan mulut mencakup semua kategori usia sebanyak $20,6 \%$ dengan spesifikasi anak yang mengalami masalah gigi dan mulut di Kalimantan Barat usia 5-9 tahun sebesar $63,5 \%$ dan usia 10-14 tahun sebesar $32,1 \%$. Selain itu, ditemukan hanya $2,9 \%$ anak yang berperilaku benar dalam menyikat gigi; anak yang masih berperilaku salah dalam menyikat gigi sebesar $97,1 \%$.

Menurut data Dinas Kesehatan Kota Pontianak tahun 2015, angka tertinggi dari upaya kesehatan gigi sekolah yang perlu perawatan sebesar 1.800 anak dari 8.649 anak di Pontianak Selatan, yaitu Puskesmas Gang Sehat. Angka tertinggi kedua sebesar 1.362 dari 3.946 anak yang perlu perawatan di Pontianak Utara, yaitu Puskesmas Siantan Tengah. Berdasarkan data dari Puskesmas Gang Sehat, pelaksanaan program pemeriksaan gigi dan mulut yang dilaksanakan pada bulan FebruariMaret, tahun 2015 didapatkan hasil 1.182; pada pada bulan Agustus dan Desember, tahun 2016 diperoleh 733 yang memerlukan perawatan.

\footnotetext{
Sesuai dengan data di atas, salah satu faktor penyebab berdasarkan keadaan kesehatan gigi
}

dan mulut, adalah kurangnya pengetahuan yang disebabkan oleh belum efektifnya penyuluhan kesehatan atau pendidikan kesehatan yakni, kurang tepatnya penggunaan metode pembelajaran untuk menjaga kebersihan gigi dan mulut.

Berdasarkan perkembangan pengetahuan, pendidik dan ahli ilmu pendidikan, pedagogik merupakan ilmu pendidikan atau ilmu mendidik. Dari perspektif pengertian pendidikan secara 'luas', tujuan itu tidak terbatas, tujuan pendidikan sama dengan tujuan hidup. Oleh karena itu, pendidikan dapat berlangsung pada tahapan anak usia dini, anak, dewasa, dan bahkan usia lanjut. Pedagogik adalah teori mendidik yang mempersoalkan apa dan bagaimana mendidik dengan baik. Menurut pengertian Yunani, pedagogik adalah ilmu menuntun anak yang membicarakan masalah atau persoalan-persoalan dalam pendidikan dan kegiatan-kegiatan mendidik, antara lain seperti tujuan pendidikan, alat pendidikan, cara melaksanakan pendidikan, anak didik, pendidik dan sebagainya. Oleh sebab itu, pedagogik dipandang sebagai suatu proses atau aktifitas yang bertujuan agar tingkah laku manusia mengalami perubahan (Kurniasih dan Sani, 2007:89).

Ada sepuluh alasan yang bersifat pedagogik untuk pemanfaatan permainan dalam proses pembelajaran yaitu, motivasi, berpusat kepada siswa, bersifat personal, meningkatkan proses pembelajaran, kaya akan perpaduan media, tetap aman walau terjadi kesalahan, umpan balik yang cepat, banyak bersifat praktis, dan membantu serta banyak bersifat kolaborasi (D. Clarck, 2006). Pada pendekatan pendidikan kesehatan gigi, dipilihlah permainan ular tangga sebagai media pembelajaran dengan metode pedagogik seperti yang telah diuraikan di atas untuk mengedukasi 
anak didik agar pendidikan yang dilaksanakan dapat berjalan sesuai dengan harapan kita semua.

Hasil penelitian yang dilakukan oleh Sara (2016) dengan judul "Efektivitas Metode Pendidikan Kesehatan dengan Simulasi Permainan Ular Tangga terhadap Perubahan Sikap tentang Kesehatan Gigi dan Mulut Anak Usia Sekolah di SDN 03 Singkawang Tengah" menunjukkan bahwa pada uji Wilcoxon skor pengetahuan pada kelompok perlakuan menunjukkan bahwa nilai- $p$ ( $p$-value)nya adalah 0,000 dan pada kelompok kontrol nilai- $p$ ( $p$-value)nya adalah 0,002.

Skor sikap pada kelompok perlakuan nilai $p$ value 0,000 dan pada kelompok kontrol nilai- $p$ ( $p$-value)nya adalah 0,001. Perbedaan 'mean' kedua kelompok diuji dengan Uji Mann-Whitney dengan nilai skor pengetahuan dan sikap pada kelompok perlakuan dan kontrol dengan nilai- $p$ ( $p$-value $)>0.05$. Ini menunjukkan bahwa permainan ular tangga dapat direkomendasikan sebagai metode alternatif baru yang menarik sebagai metode penyuluhan kesehatan dengan adanya perbedaan skor pengetahuan dan sikap antara kelompok perlakuan yang diberikan pendidikan kesehatan melalui permainan ular tangga dan kelompok kontrol.

Purnanindya (2013) pada riset "Pengembangan Permainan Edukasi Ular Tangga sebagai Media Pembelajaran TIK untuk Siswa Kelas 3 SD Negeri Pujokusuman 2 Yogyakarta" melaporkan bahwa tingkat validasi pengembangan game edukasi ular tangga dari validator ahli materi sebesar 3,39 yaitu, pada kategori 'layak', kemudian dari validator ahli media mendapat skor 3,06 yaitu, pada kategori 'layak', dan penilaian dari siswa mendapat skor 3,52 yaitu, pada kategori 'sangat layak'. Berdasarkan data tersebut, dapat disimpulkan bahwa game edukasi ular tangga sebagai media pembelajaran TIK yang telah dibuat layak digunakan untuk siswa Sekolah Dasar.

Studi pendahuluan yang dilakukan oleh peneliti menggunakan Permainan Ular Tangga dengan 32 sampel siswa di SD Al-Azhar Pontianak diperoleh hasil bahwa 100\% siswa mengetahui tentang permainan ular tangga, 100\% siswa tidak pernah belajar menggunakan permainan ular tangga di sekolah, $100 \%$ siswa menyetujui permainan ular tangga untuk digunakan sebagai media belajar, 97\% siswa mengatakan bahwa gambar dan warna dalam permainan ular tangga ini menarik, dan 97\% siswa mengatakan bahwa pesan yang disampaikan dalam permainan ular tangga ini bermanfaat. Dari studi pendahuluan tersebut dapat disimpulkan bahwa media Permainan Ular Tangga dinyatakan efektif dan dapat digunakan sebagai media pembelajaran dalam penelitian ini.

Kemudian, hasil pengamatan langsung dan wawancara mendalam yang telah dilakukan oleh peneliti kepada Perawat Gigi di SD Muhammadiyah 2 Pontianak menunjukkan bahwa terdapat 139 kasus siswa gigi berlubang pada tahun 2017. Siswa tersebut adalah siswa kelas IV A, IV B, IV C, IV D dan IV Cl. Sekalipun di sekolah tersebut sudah terpasang poster tentang gigi dan mulut di sekitar sekolah, namun tetap saja masih ada siswa yang giginya berlubang dan kurang perawatan.

Merujuk kepada uraian latar belakang di atas, peneliti tertarik untuk melakukan penelitian mengenai edukasi dengan media permainan ular tangga terhadap pengetahuan tentang 
kebersihan gigi dan mulut pada siswa Sekolah Dasar di Pontianak (Studi kasus SD Muhammadiyah 2 Pontianak).

\section{METODE}

Metode penelitian ini adalah penelitian Quasi Experiment dengan Pre and Posttest Group. Penelitian dilakukan di SD Muhammadiyah 2 Pontianak pada bulan Juli 2018. Populasi penelitian ini menggunakan teknik Total Sampling dengan sampel sebanyak 40 orang dari kelas IV A, yang kemudian dibagi menjadi 2 kelompok yaitu, 20 orang kelompok eksperimen dan 20 orang kelompok kontrol. Kedua kelompok tersebut dipilih dengan cara diundi. Kelompok eksperimen diberi perlakuan berupa bermain ular tangga, sedangkan kelompok kontrol tidak diberi perlakuan melainkan hanya diberikan Pre and Posttest saja. Data dianalisis dengan menggunakan teknik uji statistik Paired Sample T-Test.

\section{HASIL DAN PEMBAHASAN}

Hasil penelitian diuraikan dalam table berikut:

Tabel 1. Distribusi Frekuensi Responden Berdasarkan Karakteristik dan Pengalaman Bermain Ular Tangga di SD Muhammadiyah 2 Tahun 2018

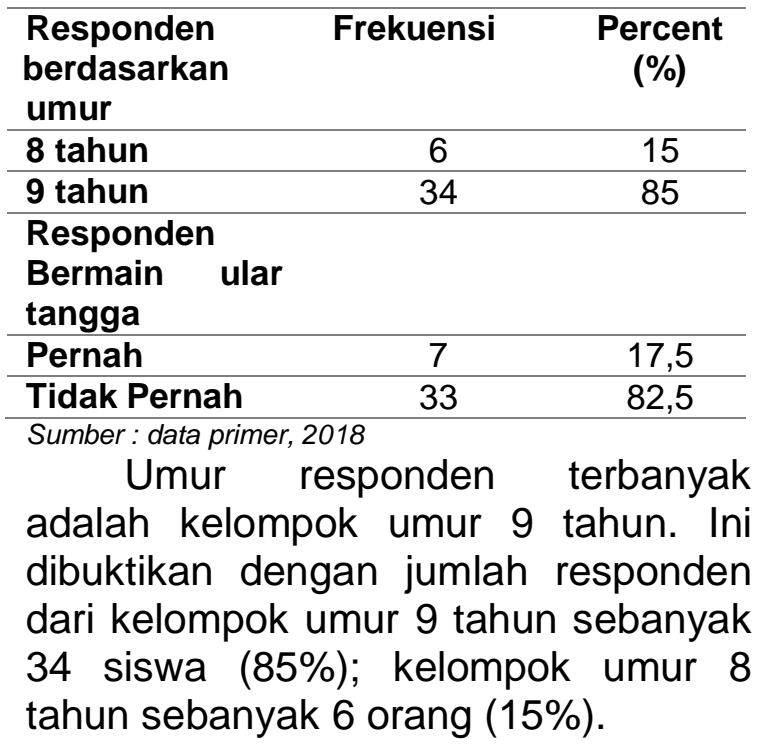

Proporsi pengalaman responden yang pernah bermain Ular Tangga lebih sedikit, 7 responden (17,5\%) diabandingkan dengan jumlah responden yang tidak pernah bermain Ular yaitu, 33 responden $(82,5 \%)$.

Tabel 2. Distribusi Frekuensi Responden Berdasarkan Pengetahuan Pretest dan Posttest Kelompok Eksperimen dan Kontrol di SD Muhammadiyah 2 Tahun 2018

\begin{tabular}{lcccc}
\hline $\begin{array}{l}\text { Kategori } \\
\text { Pengetahuan }\end{array}$ & $\begin{array}{c}\text { Pre } \\
\text { Test }\end{array}$ & \multicolumn{3}{c}{$\begin{array}{c}\text { Postt } \\
\text { est }\end{array}$} \\
\cline { 2 - 5 } Eksperimen & F & $\%$ & F & $\%$ \\
\hline Baik & 11 & 55 & 12 & 60 \\
\hline Kurang Baik & 9 & 45 & 8 & 40 \\
\hline Kontrol & & & & \\
\hline Baik & 8 & 40 & 6 & 30 \\
\hline Kurang Baik & 12 & 60 & 14 & 70 \\
\hline Sumber : data primer, 2018 & & &
\end{tabular}

Seperti dapat dilihat pada Tabel 2, jumlah responden yang memiliki pengetahuan baik pada saat pretest adalah 11 orang (55\%), sedangkan yang memiliki pengetahuan kurang baik pada saat pretest sebanyak 9 orang (45\%). Pada saat posttest, jumlah responden yang memiliki pengetahuan baik adalah 12 orang $(60 \%)$, sedangkan yang memiliki pengetahuan kurang baik adalah 8 orang $(40 \%)$.

Jumlah responden dari kelompok kontrol yang memiliki pengetahuan baik pada saat pretest adalah 8 orang (40\%) dan responden yang memiliki pengetahuan kurang baik pada saat pretest sebanyak 12 orang $(60 \%)$, sedangkan jumlah responden yang memiliki pengetahuan baik pada saat posttest adalah 6 orang (30\%), dan responden yang memiliki pengetahuan kurang baik sebanyak 14 orang (70\%). 
Hasil Uji Beda Rata-Rata Pengetahuan siswa menggunakan Uji Paired Sample $T$-Test dan Uji Independent Sample TTest adalah sebagai berikut:

Tabel 3. Perbedaan Tingkat Pengetahuan Responden Kelompok Eksperimen dan Kontrol yang Dianalisis Menggunakan Uji Paired Sample T-Test

Uji Paired Sample T- Test

\begin{tabular}{|c|c|c|c|c|c|}
\hline $\begin{array}{l}\text { Pengeta } \\
\text { huan }\end{array}$ & $\mathrm{N}$ & Mean & SD & Selisih & $\begin{array}{c}\mathrm{P} \\
\text { Value }\end{array}$ \\
\hline \multicolumn{6}{|c|}{ Eksperimen } \\
\hline Pretest & \multirow{2}{*}{20} & 52,25 & 10,19 & \multirow{2}{*}{37} & \multirow{2}{*}{0,000} \\
\hline Posttest & & 89,25 & 5,20 & & \\
\hline \multicolumn{6}{|l|}{ Kontrol } \\
\hline Pretest & \multirow{2}{*}{20} & 52,25 & 5,73 & \multirow{2}{*}{3} & \multirow{2}{*}{0,137} \\
\hline Posttest & & 55,25 & 7,69 & & \\
\hline
\end{tabular}

Sumber : data primer, 2018

Seperti terlihat pada Tabel 3, pada Uji Paired Sample T-Test kelompok Eksperimen 1, nilai mean pengetahuan siswa pada saat dilakukannya pretest sebesar 52,25 dengan standar deviasi 10,19 dan pada saat posttest sebesar 89,25 dengan standar deviasi 5,20. Perubahan pengetahuan tersebut signifikan dengan $\mathrm{p}$-value $=0.000$. Hasil penelitian menunjukkkan perbedaan nilai rata-rata pengetahuan sebelum dan setelah intervensi sebesar 37 poin.

Uji Paired Sample T-Test kelompok kontrol juga menunjukkan tidak adanya peningkatan pengetahuan siswa yang signifikan. Pengetahuan siswa kelompok kontrol sebelum dilakukannya intervensi dengan menggunakan Media Permainan Ular Tangga sebesar 52,25 dengan standar deviasi 5,73 dan setelah dilakukan intervensi pengetahuannya menjadi 55,25 dengan standar deviasi 7,69. Perubahan pengetahuan tersebut tidak signifikan dengan $p$-value $=0.137$. Perbedaan nilai rata-rata pengetahuan sebelum dan setelah intervensi adalah 3 poin.

Hasil penelitian ini menunjukkan adanya peningkatan pengetahuan pada kedua kelompok penelitian dari pretest dan posttest. Nlai mean pretest dari kelompok eksperimen sebesar 52,25 dan setelah posttest nilai meannya sebesar 89,25 . Nilai mean pretest kelompok kontrol adalah 52,25 dan setelah posttest nilai meannya sebesar 55,25. Hasil ini menunjukkan adanya peningkatan pengetahuan dari 2 kelompok tersebut karena didukung oleh media permainan ular tangga yang menjadi media pembelajarannya. Penurunan dan peningkatan pengetahuan siswa tersebut dipengaruhi oleh media permainan ular tangga baik melalui konten gambar maupun pesannya.

Pengetahuan merupakan aspek yang penting dalam diri seseorang untuk dapat mengakses segala bentuk perubahan dalam kehidupan. Dengan pengetahuan, seseorang akan lebih mudah mencari solusi pemecahan segala persoalan kehidupan. Di sisi lain, keadaan pengetahuan siswa yang kurang baik juga dimungkinkan karena perbedaan umur yang membuatnya tidak memiliki wawasan pengetahuan di luar lingkungannya (Depkes RI, 2005). Selisih nilai mean antara kelompok eksperimen, 89,25, dan kelompok control, 55,25, adalah 37 
point. Dari besaran selisih ini, penghitungan Effect Size (Besar Pengaruh) media permainan ular tangga terhadap pengetahuan kebersihan gigi dan mulut pada siswa dapat dilakukan.

Menurut penelitian Fitriastutik (2010) yang berjudul "Efektivitas Booklet dan Permainan Tebak Gambar dalam Meningkatkan Pengetahuan dan Sikap Siswa Kelas IV Terhadap Karies Gigi di SD Negeri 01, 02, dan 03 Bandengan Kecamatan Jepara Kabupaten Jepara Tahun Ajaran 2009/2010" yang memiliki nilai mean pada kelompok intervensi dengan media booklet sebesar 18,67 dan kelompok kontrol sebesar 3,11 dengan selisih 15,56 point, jika dibandingkan dengan media permainan ular tangga dalam penelitian ini yang memiliki selisih 37 point, maka media permainan ular tangga lebih efektif daripada media booklet.

Selain itu, penelitian Fitriastutik (2010) juga menerapkan intervensi dengan media Tebak Gambar, dimana kelompok intervensinya memiliki nilai mean sebesar 12,89 dan kelompok kontrolnya 3,11 dengan selisih 9,78 point, jika dibandingkan dengan media permainan ular tangga dalam penelitian ini yang memiliki selisih 37 point, maka media permainan ular tangga lebih efektif daripada media Tebak Gambar.

Sedangkan penelitian Jannah (2016) dengan judul "Perbedaan Pengaruh Pendidikan Kesehatan Tentang Karies Gigi Melalui Media Buku Cerita Bergambar dan Leaflet terhadap Pengetahuan, Sikap, dan
Perilaku anak Sekolah Dasar di Kabupaten Malang" memiliki nilai mean pada kelompok perlakuan dengan media Buku Cerita Bergambar sebesar 19,10 dan kelompok perlakuan dengan media Leaflet sebesar 14,87 sehingga memiliki selisih sebesar 4,23 point yang berarti media Buku Cerita Bergambar lebih efektif daripada Leaflet, jika dibandingkan dengan media permainan ular tangga dalam penelitian ini yang memiliki selisih 37 point, maka media permainan ular tangga lebih efektif daripada media Buku Cerita Bergambar.

Hasil penelitian ini didukung oleh penelitian Kurniawati (2017) yang berjudul "Pengaruh Permainan Ular Tangga terhadap Pengetahuan dan Sikap dalamMenghadapi Menarche pada Siswi SDN Pringgowirawan 01 Sumberbaru Kabupaten Jember", yang mengatakan bahwa skor rata-rata pretest pengetahuan siswi pada kelompok perlakuan adalah 46,6 dan skor rata-rata posttest pengetahuan siswi pada kelompok perlakuan adalah 86,7. Dari hasil tersebut, dapat diketahui bahwa skor mean posttest 86,7 lebih baik daripada mean pretest yang bermakna bahwa telah terjadi peningkatan pengetahuan pada siswi di SDN Pringgowirawan 01 Sumberbaru Kabupaten Jember sesudah diberi intervensi dengan media permainan ular tangga. Skor rata-rata pretest pengetahuan siswi kelompok kontrol adalah 66,7 dan skor rata-rata posttest pengetahuan siswi kelompok kontrol adalah 33,3. Dari hasil tersebut dapat diketahui bahwa skor mean posttest 33,3 lebih rendah 
daripada mean pretest 66,7. Ini bermakan bahwa telah terjadi penurunan pengetahuan pada siswi SDN Pringgowirawan 01 Sumberbaru Kabupaten Jember sesudah diberi intervensi dengan media permainan ular tangga. Dalam penelitian ini ratarata pengetahuan pretest pada kelompok eksperimen adalah 52,25 dan posttest 89,25. Hasil tersebut menunjukkan bahwa skor mean posttest lebih baik daripada pretest 52,25. Maknanya adalah telah terjadi peningkatan pengetahuan pada siswa. Skor rata-rata pengetahuan pretest kelompok kontrol adalah 52,25 dan skor rata-rata pengetahuan posttest kelompok ini adalah 55,25. Perubahan pengetahuan tersebut tidak mengalami peningkatan yang signifikan dengan $\mathrm{p}$ value 0,137 . Hasil penelitian tersebut mendukung penelitian sebelumnya bahwa intervensi menggunakan media Permainan Ular Tangga lebih efektif untuk meningkatkan pengetahuan daripada tidak mengunakan media tersebut.

$$
\text { Penelitian Siyam (2015) }
$$

"Pengaruh Stimulasi Permainan Ular Tangga Tentang Gingivitis terhadap Pengetahuan Anak Usia 8-11 tahun" pada siswa di SDN Kuningan 04, Kecamatan Semarang Utara, membuktikan bahwa pengetahuan pretest and posttest responden terlihat dari peningkatan rata-rata pengetahuan setelah diberi intervensi berupa permainan ular tangga yaitu, pretest sebesar 11,06 dengan standar deviasi 2,58 dan posttest sebesar 13,01 dengan standar deviasi 2,73. Hasil tersebut menyatakan bahwa terdapat penyuluhan menggunakan stimulasi permainan ular tangga tentang gingivitis terhadap peningkatan pengetahuan anak usia 8-11 tahun. Di dalam penelitian ini rata-rata pengetahuan pada kelompok eksperimen rata-rata pengetahuan pretest adalah 52,25 dengan stadar deviasi 10,19 dan rata-rata pengetahuan posttest adalah 89,25 dengan standar deviasi 5,20. Terlihat perbedaan nilai rata-rata pengetahuan sebelum dan sesudah intervensi media permainan ular tangga. Ini artinya bahwa setelah bermain permainan ular tangga, pengetahuan responden mengalami peningkatan. Perubahan pengetahuan tersebut signifikan dengan $p$-value 0,000 . Hasil penelitian tersebut mendukung penelitian sebelumya bahwa intervensi menggunakan media permainan ular tangga efektif untuk menigkatkan pengetahuan.

Diperkuat juga oleh penelitian Sara (2016) yang berjudul "Efektifitas Metode Pendidikan Kesehatan dengan Simulasi Permainan Ular Tangga terhadap Perubahan Sikap Tentang Kesehatan Gigi dan Mulut Anak Usia Sekolah di SDN 03 Singkawang Tengah", mengatakan bahwa skor rata-rata pengetahuan siswa yang diberi intervensi dengan media permainan ular tangga dengan pretest sebesar 32,25 dan posttest sebesar 34,17. Hasil tersebut menunjukkan tentang adanya peningkatan pengetahuan pada siswa tentang kesehatan gigi dan mulut setelah pemberian intervensi dengan media permainan ular tangga. $\mathrm{Di}$ dalam penelitian ini rata-rata pengetahuan pretest kelompok eksperimen adalah 
52,25 dengan stadar deviasi 10,19 dan rata-rata pengetahuan posttest adalah 89,25 dengan standar deviasi 5,20. Terlihat perbedaan nilai rata-rata pengetahuan sebelum dan sesudah intervensi media permainan ular tangga. Ini artinya setelah bermain permainan ular tangga, pengetahuan responden mengalami peningkatan. Perubahan pengetahuan tersebut signifikan dengan $p$-value 0,000 . Hasil penelitian tersebut mendukung penelitian sebelumya bahwa intervensi menggunakan media permainan ular tangga efektif untuk menigkatkan pengetahuan.

Media yang menggunakan gambar (visual) lebih disukai anak daripada yang hanya menggunakan tulisan saja. Hal tersebut didukung oleh beberapa penelitian yang menggunakan media tulisan dan gambar, seperti Abduh Ridha \& Tedy Dian Pradana (2017) yang melelukan penelitian dengan judul "Pengaruh Media Komik terhadap Pengetahuan Kesehatan Mata Pada Anak" yang melaporkan bahwa gambar yang disajikan didalam komik pendidikan berbentuk kartun. Alasannya adalah karena anak-anak menyukai gambargambar kartun. Fungsi gambar tersebut hanya sebagai ilustrasi dari cerita yang disajikan yang sesuai dengan materi yang dibahas ditambah dengan pemberian warna pada komik yang tentunya memiliki daya tarik tersendiri untuk menarik minat anak dalam membaca. Menurut penelitian Abduh Ridha \& Selviana (2016) yang berjudul "Efektivitas Media Komik pada Pengetahuan dan Sikap Mengenai Cuci Tangan Pada Siswa Sekolah
Dasar", media komik merupakan media pengajaran yang menyebabkan proses belajar siswa menjadi lebih mearik yang kemudian dapat mempengaruhi perilaku siswa. Selain itu, komik terbukti mampu membantu anak dalam proses belajar membaca, karena komik memberikan materi yang menarik dan memotivasi serta dilengkapi dengan dukungan visual.

Berdasarkan hasil penelitian yang telah dilakukan, pemberian edukasi dengan media permainan ular tangga mempengaruhi perubahan tingkat pengetahuan siswa. Dilihat dari hasil penelitian yang telah dilakukan oleh peneliti, terjadi peningkatan nilai posttest pada siswa yang telah diberi intervensi dengan metode pendidikan kesehatan yaitu, media permainan ular tangga. Peningkatan tersebut dilihat dari jawaban siswa yang menjawab benar dari pretest pada soal nomor 3 yaitu, "Dari gambar di samping, makan-makanan manis dan lengket dapat menyebabkan?" dengan jawaban "menyebabkan plak gigi dan menimbulkan karies gigi", hanya sebesar $30 \%$ siswa saja yang dapat menjawab dengan benar. Ini berarti bahwa $70 \%$ siswa tidak tahu bahwa penyebab dari makan-makanan manis dan lengket tersebut dapat menyebabkan plak pada gigi dan menimbulkan karang. Kemudian, setelah mendapatkan intervensi melalui edukasi dengan media Permainan Ular Tangga, siswa kembali diuji pengetahuannya dengan posttest dan hasilnya $100 \%$ siswa dapat menjawab dengan benar pada soal nomor 3 tersebut. Ini berarti bahwa setelah mendapat intervensi, siswa 
menjadi tahu dampak dari makanmakanan manis dan lengket tersebut. Kemudian, tidak terjadi peningkatan yang signifikan terhadap pengetahuan siswa yang tidak diberi intervensi. Pada permainan ular tangga ini responden membaca pernyataan tentang akibat positif negatifnya tentang perlakuan kebersihan gigi dan mulut yang terdapat di dalam permainan ular tangga. Aktivitas ini melibatkan indera penglihatan dan pendengaran, sehingga informasi dapat mudah dicerna. Kelebihan lain dari permainan ular tangga ini adalah dapat memberikan umpan balik secara langsung kepada responden. Umpan balik ini dilakukan dengan cara membahas pernyataan yang terdapat dalam tiap kotak permainan ular tangga dengan cara membacakannya, sehingga informasi yang diterma dapat langsung dicerna.

Dilihat dari jumlah pemainnya, permainan ular tangga ini dilakukan dalam kelompok kecil yaitu, maksimal 4 orang. Dengan jumlah anggota pemain yang sedikit, suasana mudah dikendalikan dan tidak akan terdistraksi dengan hal lain yang memecah konsentrasi, sehingga informasi yang didapat mudah untuk dicerna, dibandingkan dengan responden yang tidak diberi edukasi dengan media permainan ular tangga. Selain itu, metode permainan ular tangga merupakan salah satu metode pembelajaran koperatif yang memberikan kesempatan kepada responden untuk melakukan interaksi dan berpartisipasi aktif selama intervensi berlangsung. Dibandingkan dengan yang tidak diberi intervensi responden hanya menerima pretest dan posttest, sehingga tidak memberikan akses bagi mereka untuk berkembang secara mandiri melalui proses berpikirnya dalam mengolah informasi. Metode pendidikan dengan media permainan ular tangga ini lebih menarik dan efektif untuk meningkatkan pengetahuan siswa.

\section{KESIMPULAN}

Temuan penelitian ini adalah adanya perbedaan yang bermakna peningkatan pengetahuan siswa tentang Kebersihan Gigi dan Mulut di SD Muhammadiyah 2 Pontianak antara sebelum dan sesudah diberikan edukasi dengan media Permainan Ular Tangga. nilai rerata pretest kelompok eksperimen sebesar 52,25 meningkat menjadi 89,25 di posttest. Perubahan pengetahuan tersebut signifikan dengan p-value 0,000.

Tidak ada perbedaan bermakna mengenai peningkatan pengetahuan siswa tentang kebersihan gigi dan mulut di SD Muhammadiyah 2 Pontianak antara sebelum dan sesudah diberikan pretest dan posttest. Nilai rerata pretest kelompok kontrol adalah sebesar 52,25 dengan standar deviasi 5,73, dan setelah diberikan perlakuan nilai reratanya meningkat menjadi 55,25 dengan standar deviasi 7,69 pada posttestnya. Perubahan pengetahuan tersebut tidak signifikan dengan $p$-value 0,137.

\section{Pendidikan kesehatan gigi} tentang kebersihan gigi dan mulut dalam hubungannya dengan perilaku hidup sehat itu penting karena tingkat kesehatan merupakan salah satu faktor yang menentukan Indeks Pembangunan Manusia (IPM). 


\section{REKOMENDASI}

Berdasarkan hasil penelitian yang telah dilakukan, ada beberapa saran yang ditujukan kepada pihak-pihak yang mempunyai kepentingan antara lain:

1. Dinas Kesehatan diharapkan dapat memanfaatkan media Permainan Ular Tangga sebagai media promosi kesehatan dan dapat memonitoring program promosi kesehatan tentang kebersihan gigi dan mulut di sekolah-sekolah.

2. Siswa SD Muhammadiyah 2 Pontianak diharapkan dapat menambah pengetahuannya tentang masalah kebersihan gigi dan mulut dengan cara mengikuti pendidikan kesehatan individu maupun kelompok dengan menggunakan media maupun alat bantu lainnya seperti media Permainan Ular Tangga.

3. Pihak SD Muhammadiyah 2 Pontianak diharapkan sebagai pihak sekolah yang dapat memanfaatkan Permainan Ular Tangga sebagai salah satu media untuk mengajarkan kebersihan gigi dan mulut dan juga sebagai media promosi kesehatan di sekolah yang dapat dimasukkan kedalam salah satu pelajaran yang menyangkut kesehatan, misalnya, mata pelajaran muatan lokal, pendidikan jasmasi dan kesehatan, atau biologi.

4. Peneliti lain diharapkan dapat menggunakan media Permainan Ular Tangga tentang kebersihan gigi dan mulut dalam ukuran yang lebih kecil, agar praktis dimainkan di manapun dan kapanpun oleh responden; mengatur posisi tempat duduk responden dengan jarak yang berjauhan agar responden satu dan responden lainnya tidak dapat saling berdiskusi tentang pertanyaan dari dalam kuesioner pretest dan posttest yang diberikan; menyesuaikan waktu pretest dan posttest sehingga responden tidak mengingat pertanyaan didalam kuesioner; meneliti tentang perubahan perilaku kebersihan gigi dan mulut pada responden yang sudah diberi intervensi. Hal ini memungkinkan untuk menganalisis pengaruh intervensi dengan media Permainan Ular Tangga terhadap perubahan perilaku.

\section{DAFTAR PUSTAKA}

Abduh Ridha, Pradana, 2017. Pengaruh Media omik Terhadap Pengetahuan Kesehatan Mata Pada Anak., Fakultas IImu Kesehatan Universitas Muhammadiyah Pontianak. Jurnal Vokasi Kesehatan, Vol.3 Nomor 2, 2017. http://ejournal.poltekkespontianak.ac.id/index.php/JVK/art icle/viewFile/111/pdf

Abduh Ridha, Selviana, 2016. Efektivitas Media Komik Pada Pengetahuan dan Sikap Mengenai Cuci Tangan Pada Siswa Sekolah Dasar, Fakultas IImu Kesehatan Universitas 
Muhammadiyah Ponianak. Jurnal LINK, $12 \quad$ (1), 2016. http://ejournal.poltekkessmg.ac.id/ojs/index.php/link/articl e/view/405/430

Balqis, A, F, 2014 Hubungan Pengetahuan Kesehatan Gigi terhadap DMF-T \& Ohis pada Anak Usia 10-12 Tahun di Makasar. Skripsi. Universitas Hasanuddin Makasar.

Depkes RI, 2015. Profil Kesehatan Indonesia. Depkes RI, Indonesia

Donald Clark. 2006. Game and elearning. Sunderland. Caspian Learning.

www.caspianlearning.co.uk

Fitriastutik, R.D, 2010. Efektivitas Booklet dan Permainan Tebak Gambar dalam Meningkatkan Pengetahuan dan Sikap Siswa Kelas IV terhadap Karies Gigi di SD Negeri 01, 02, dan 03 Bandengan Kecamatan Jepara Kabupaten Jepara Tahun Ajaran 2009/2010. Skripsi. Universitas Negeri Semarang.

Jannah Zuhrotul, 2016. Perbedaan Pengaruh Pendidikan Kesehatan Tentang Karies Gigi Melalui Media Buku Cerita Bergambar dan Leaflet Terhadap Pengetahuan, Sikap, dan Perilaku Anak Sekolah Dasar di Kabupaten Malang. Skripsi. Universitas Muhammadiyah Surakarta.

Komisi WHO. 2016. Mengenai Intervensi Kesehatan Masyarakat terhadap Karies Anak Usia Dini

http://www.who.int/iris/bitstream/1 0665/259349/1/WHO-NMH-PNDECHO-17.1eng.pdf?ua $=1$ (Diakses tanggal 6 Januari 2018)

Kurniasih, Sani. 2017. Kupas Tuntas Kompetensi Pedagogik. Jakarta: Kata Pena.

Kurniawati Dini, 2017. Pengaruh Permainan Ular Tangga terhadap Pengetahuan dan Sikap dalam Menghadapi Menarche pada Siswi SDN Pringgowirawan 01 Sumberbaru Kabupaten Jember. E-Jurnal Pustaka Kesehatan, Vol. 5 (No.1), Januari 2013.

Pintauli, 2010. Analisis Hbungana Perilaku Pemeliharaan Kesehatan gigi dan Mulut Terhadap Status Kesehatan Gigi dan Mulut Siswa SD dan SMP di Medan. Jurnal Pendidikan dan Kebudayaan Vol.16, Nomor 4, Juli 2010.

Riset Kesehatan Dasar Provinsi Kalimantan Barat. Pedoman Pewawancara Petugas Pengumpul Data. 2013.

Sara Pradhethi, 2016. Efektifitas Metode Pendidikan Kesehatan dengan Simulasi Permainan Ular Tangga terhadap Perubahan Sikap tentang Kesehatan Gigi dan Mulut Anak Usia Sekolah di SDN 03 Singkawang Tengah. Skripsi. Universitas Tanjungpura Pontianak.

Siyam, 2015. Pengaruh Stimulasi Permainan Ular Tangga Tentang Gingivitis Terhadap Pengetahuan Anak Usia 8-11 Tahun. Odonto 
Jurnal Borneo Akcaya, 05(01): 31-43, Juni 2019

Dental Journal Vol. 2 Nomor 1, Juli 2015. 